\title{
Developing Self-Assessment for Writing Competency of Grade 9 Junior High School 12 Padang
}

\author{
Elismawati, M. Zaim, and Refnaldi \\ UIN Imam Bonjol Padang \\ elismawati_1957@yahoo.com
}

\begin{abstract}
Self-assessment has become a means of realizing the goals of learner-centered education. The research aimed to develop self-assessment instruments for assessing writing skill at grade 9 SMPN 12 Padang. It is conducted: (1) to find out self- assessment instruments needed to be developed, (2) to design the prototype of the developed self-assessment instruments, (3) to discover the quality of the developed self-assessment instrument which needs to be developed. The ADDIE model of Research and Development was employed in this study, comprising of five steps including analysis, design, development, implementation, and evaluation. The result states that the teachers needed self-assessment instruments which focus on the learning development of students. The prototype of the study was developed based on syllabus analysis and teachers' need which was developed in genre based form. Besides, in order to find out the quality of the developed self-assessment instrument, the instrument developed was validated by expert judges and user judges. The result shows that the content validity of the instruments was very high and the practicality of the instrument was excellent. It can be concluded that this assessment model is applicable for teachers to assess students' writing.
\end{abstract}

Keywords-Self-Assessment, Writing competency

\section{INTRODUCTION}

English Language Teaching (ELT) has experienced a paradigm change from teacher to student-centered teaching. In traditional classroom practice, the learners are different positioned as the central figure of teaching and learning process. Harris (1997) claims that the effectiveness of teaching and learning should based on learners' perceptions of the learning process and of themselves as language learners. Furthermore, Vein, Hunt, Gow, and Barnes (1989) state that successful language teaching must start from the learners rather than the teachers. The teachers must be aware that the language learners are the most important element in the learning process. On the other hand, teachers should facilitate learners with the opportunities to develop their self-awareness of their needs, goals, and learning process.

Since mid the year 2013 in Indonesia enacted curriculum 2013, which seeks to change the habit patterns of teachers teaching and students learning. Government or other agencies typically try to help solve the various barriers faced by teachers when the teachers faced various changes to the duties and responsibilities. Various training, workshops, mentoring are provided for teachers in order they are able to implement the curriculum 2013. The teachers have to follow the curriculum changes that occur whether they like or not. Study habits at school that has done so far turned out to be changed. Students should be active and dynamic, and student must arrange their own activities to compensate for changes in teachers' teaching activities. Therefore, students need to learn how to learn, which is done in self-regulated learning abilities.

The teacher must be prepared a well-planned teaching and learning plan and material in order to meet the purpose of Curriculum 2013. In order to assess the student's competency level, and to determine the quality and the quantity of the student's ability, the assessment must be conducted. Nitko (1996) claims that assessment in education helps teachers to make a better decision regarding teaching the strategic acquisition of language skills. Arranging a well-defined assessment tool can help the teacher design appropriate teaching resources. The teacher needs to decide which skills, processes or knowledge they want to assess. Consequently, it is very significant for the teacher to develop appropriate assessment for the students.

Language learners are considered mastering the language when they can master the four skills of language learning which are listening, speaking, reading, and writing. From the four skills, writing is considered one of the most important skills to be learned. Writing is a productive skill that requires enough time to think about the specific topic, to analyze and to classify any background knowledge. It means writing integrates several processes such as: finding the topic, providing information to support the content of the topic, classifying ideas, organizing ideas in logical sequence and implementing linguistics knowledge.

Writing is a skill that can be defined as an exploration of any thought or anything to be formed in writing. According to Coulmas (2003:19), writing is visible. It is a form of communication created by the hand and appealing to the eyes. Thus, this definition states that writing is a very important process that has meaning in communication. By writing, the students can also have knowledge about good structure to make a fine writing. Writing is a medium for the students to organize their thoughts 
in an excellent way in writing. Thus, it can be said that writing is an important skill that must be had by the students.

In order to improve students' writing ability, the teacher should know the students' level of competency in writing, so the teacher can design further strategies to improve the students' writing skill. Self- assessment is considered a good way to improve the students' writing competency since it will lead the students to become aware of their own ability. By giving selfassessment, the students can develop a more active and responsible role in their own learning.

There are some opinions among the definition of self- assessment. Richard and Schmidt (2002, p. 475) state selfassessment as "checking one's own performance on a language learning task after it has been completed". They claim that self-assessment is an example of meta cognitive strategy in language learning Self-assessment, also known as selfevaluation, or self-rating, is defined here as a process in which students are asked to estimate their own knowledge, skills, and performance. Brown 2005:58 claims that student self-assessment is considered a powerful tool to raise consciousness about language learning among students and as a means to encourage active, self-directed language learning.

Regarding the importance of self- assessment, the teacher has to assist the students to do the self-assessment by providing the students with relevant directions, material and instruments. Unfortunately, based on the preliminary observations conducted at SMP N 12 Padang, it was found that very few teachers used relevant instrumentation to assess the students' competency. Many teachers only rely on the available tasks and the assessment instruments obtained from a certain book that the school bought. Some of the instruments used might not be relevant if the teacher does not modify the instrument based on the students' competency level. Therefore, they struggled to develop a relevant instrument for assessing the students' writing.

Developing a relevant instrument for the students help the teacher conduct a meaningful assessment. In order to provide a relevant instrument for junior high school students, this research was focused on developing self-assessment instruments. It is hoped that this research will make a meaningful contribution to the development of writing skills in junior high schools 12 Padang.

Based on the explanation above, this study aimed to identify self- assessment instruments needed to be developed, designing the prototype of the developed self-assessment instruments, discovering the quality of the developed self-assessment instrument developed. This study was expected to provide a beneficial contribution for the teachers, students and the schools. Through the findings of this research, the teacher could be provided with a worthwhile example of a relevant instrument for assessing students' competency which will further improve the students' English competency. The school could also benefit from the findings of this research because the findings will enrich references for teachers' professional development.

\section{METHOD}

The type of this research was research and development ( $R$ and D). This research was focused to develop self assessment for writing skill. Researcher developed authentic assessment and also applied it to the students particularly for grade 9 SMPN 12 Padang. Researcher used ADDIE model which was developed by Branch (2009: 17). It provides instructional designers with a framework in order to make sure that their instructional products are effective and that their creative processes are as efficient as they can possibly be. ADDIE stands for the steps of the model including Analysis, Design, Development, Implementation, and Evaluation. Each step has an outcome that feeds the subsequent step. Evaluation is essential after each step.

There were five phases had been conducted in this research. It was started by analyzing the need analysis on authentic assessment for writing skill and ended by evaluating the new model through perception of the users. Completely, those phases were presented as follows:

Analyze

Firstly, in analyzing stage the researcher interviewed 3 English teachers of SMP N 12 Padang to discuss the issues questionnaire to discover the actual needs of the self-assessment instruments that was going to be developed. In this stage, the syllabus analysis was also conducted because it was important data for developing the need analysis questionnaire.

\section{Designing}

Secondly, in designing stage the researcher designed objectives of self-assessment and then continued by designing the self- assessment needed to be developed for SMP N students at 12 Padang. Some literature review was also conducted in order to find out the self-assessment procedure.

\section{Developing}

Thirdly, in developing stage, the draft was developed to result the instrument draft. The instrument draft was developed by looking at the basic competency to find out the genre of writing of grade 9 junior high school. The instruments were then developed consisting of lesson plan, learning materials, writing task, writing planning checklist, draft checklist, and self reflection. Implementing

\section{Evaluating}

Fourthly, in implementing stage, the instruments were measured by expert judges and user judges.

Fifthly, in evaluating stage, data analysis was conducted and the feedback obtained from the user judges and expert judges was used to revise the instruments being developed. In this research, due to limitation of time, the procedure was conducted up to the stage of development and then followed up with content validity and practicality check. The content validity 
was measured by expert judges and the practicality was measured by teachers as user judges. The self-assessment instruments in terms of content validity were measured by expert judges by using Gregory formula, where score 5 is Excellent, 4 is Good, 3 is Average, 2 is Below Average, and 1 is Poor.

\section{FINDING AND DISCUSSION}

To answer the first research question, need analysis was conducted in order to investigate the self-assessment needed to be developed. It was conducted in SMP N 12 Padang by administering questionnaire to the teachers as well as conducting interview after the questionnaire was collected.

From the data analysis it was found that the type of self-assessment needed by teachers was self-assessment which focuses on the learning development of students considering the students' different level of competency and the syllabus of Grade 9 junior high school. Furthermore, the writing task developed also need to be differentiated based on students' level of competency (complex, and simple). By giving the different level of task based on students' competency, the students who have higher level of competency will develop their competency and the students who have lower level of competency will still get the target of the learning.

The findings of the need analysis questionnaire are of 6 indicators as follows: (1) Teachers claim that writing is a complex skill which require students to master the other skill of language. Writing is a productive skill that make the writer need to read or listen about a certain information first before writing the ideas. It is in line with Byrn (1993) who states that writing is transforming thoughts into language. (2) Self- assessment helps students realize their own competency. The students will get feedback for their own self by administering self- assessment in the classroom. The use of self-assessment and self access learning enables learners to reflect on their progress and such revision enables learners to take more control of their learning and to be responsible (Gardner and Miller in Srimavin and Pornapit, 2004). (3)The teacher needs a clear guideline on the application of self-assessment in the classroom in order to help them to apply the self-assessment in the correct way. (4) Teachers found difficulties in applying an appropriate self-assessment writing. It happen because the teacher believes that it is time consuming and the teachers are not really aware of the appropriate way in developing self-assessment in writing. (5) Teachers would like to have a self-assessment which focuses on the learning development of students in order to produce a better result of students' product. Focusing the self-assessment in the process of writing, the students can make decisions for themselves, not waiting for the teacher to tell them if they understand (6) Teachers are aware of the different levels of competence of each student because the teachers are always dealing with the students. The teachers know the students competency by the students' performance in the classroom. It is in line with the criteria of authentic assessment proposed by Wiggins (1990) which stated that assessment is authentic when it directly examines students' performance on worthy intellectual task which is in this case design in competency based.

The second objective of this study is to design the prototype of the developed self-assessment. The prototype was designed based on the need analysis and syllabus analysis. The need analysis was obtained by administering a questionnaire and conducting interview to nine grade junior high school teacher in SMP N 12 Padang. Analyzing the syllabus was conducted in order to find out the scope of the instrument being developed. In the syllabus, there are two basic competencies that were developed. There are three genre of writing namely report, narrative, and procedure from the first and second semester. Thus, the development of self-assessment instrument for this present study covered those three genres of writing. The result of all the analysis was then combined to create the prototype. Bellow is the figure of the prototype designed.

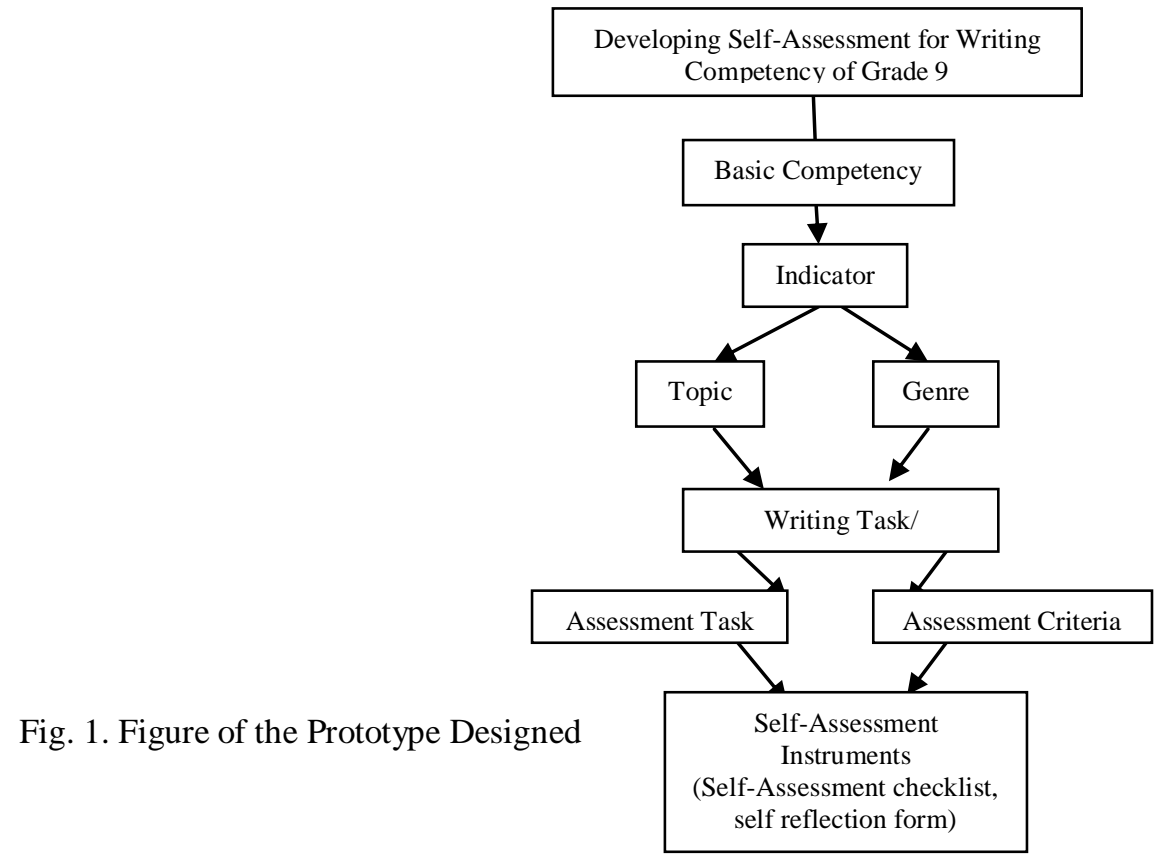


The prototype was designed by considering the standard competency and basic competency of the writing skill of grade 9 junior high school students in SMP N 12 Padang which consist of two points of standard competency and two points of basic competency.

The standard competencies are (1) Expressing the meaning of functional text and short essay in the form of report and procedure text to interact with surrounding environment. (2) Expressing the meaning of functional text in the form of report and narrative text to interact with surrounding environment.

The basic Competencies are (1) Expressing meaning and rhetorical steps in short simple essay by using a variety of written language accurately, fluently, and acceptably to interact with surrounding environment in the form of report and procedure text, (2) Expressing meaning and rhetorical steps in short simple essay by using a variety of written language accurately, fluently, and acceptably to interact with surrounding environment in the form of procedure and narrative text.

Furthermore, Indicators were developed based on the genres in the basic competencies and standard competencies. The genres are report, narrative and procedure. For report text, the indicators are (1) Filling in the gap of report text, (2) Arranging sentence into a meaningful report text, (3) Developing a short simple essay in the form of report text. For procedure text, the indicators are (1) Filling in the gap of procedure text, (2) Arranging sentence into a meaningful procedure text, (3) Developing a short simple essay in the form of procedure text. For the narrative text the indicators are (1) Filling in the gap of narrative text, (2) Arranging sentence into a meaningful narrative text, (3) Developing a short simple essay in the form of narrative text.

The writing activities were developed based on the indicators of the first and second semester such as filling in the gap text and arranging sentence into a meaningful paragraph. Furthermore, the assessment criteria was developed considering Grammar, mechanic, vocabulary, content, organization, generic structure as well as the characteristic from each genre. The characteristics of Report, Procedure, and Narrative text were used as guidance to develop the blue print and the instrument.

Assessment tasks were developed According to Harmer (2004), involving four elements in writing process, namely planning in which the writer plans what they are going to write, drafting in which the writer puts down his/her ideas into words, editing in which the writer corrects the mistakes in the writing, and the final version in which the writer has done the final version of his/her writing.

The self-assessment instruments developed in this present study concerns the self-assessment process focusing on the development of students' writing. Andraide and Valtcheva (2009) claim that it was designed with three processes proposed which are used in the process of conducting the self-assessment in the classroom. The three processes consist of articulating expectations, self-assessment, and revision. In the articulating expectations stage, the goal was articulated by the blue-print of self-assessment. Furthermore in the self- assessment stage, the students were supposed to examine themselves by using the self-assessment developed and the last part was revision in which the students used feedback from the self-assessment conducted before revising their writing.

According to Marhaeni (2005) the assessment criteria focused on the development of quality of ideas, the understanding of the topic selected, and the arrangement of ideas, during the writing process as well as the five dimensions of writing; content, Ideas organization, sentence structure, vocabulary and mechanics. .The instruments were developed based on the genre of text in the syllabus. There were 3 genres in the syllabus namely Report, Narrative and Procedure. The items of the self-assessment checklist were referring to the aspects of each genre.

Langan (2002) says that the items for the self-assessment checklist were developed based on the criteria of good grammar, mechanic, content, organization, and vocabulary. Besides, the checklist for generic structure of report, narrative, and procedure texts were developed in line with Sorenson (2000). The criteria for report text are (1) general classification talks about what the phenomenon under discussion (2) description explains the phenomenon in terms of parts (and their function), qualities, and habits or behavior (3) language features usually uses simple present tense. Those criteria of descriptive text above were used as a guidance for the developing the blue print of self- assessment.

The finding of this study shows that the content validity of the instrument (using Gregory formula) was one (1), which was classify as very high referring to the validity criteria by Candiasa (2012). The practicality of the instruments developed was excellent $(35.75 \leq 36.5<44)$ referring to the criteria proposed by Fernandes in Dantes (2012) which states that Mi + 1.5 Sdi $\leq \mathrm{Sr}<\mathrm{Mi}+3.0 \mathrm{Sd} \mathrm{i}=$ excellent.

Since the instruments were developed by using relevant model design, it resulted valid instruments that will impact the success of the implementation of this instrument in the classroom. On the other hand, it can be said that the instrument is ready to be used by junior high schools teachers at SMP N 12 Padang to assess students' writing competency.

Thereby, the development of self- assessment instrument in this present study was focused on the process of writing which means the teachers are aware of the importance self-assessment in the process of writing. By implementing the selfassessment in writing, the students will be aware of their own strength and weaknesses in writing. It will then encourage students to judge the quality of their own work based on the assessment criteria which is stated in the self- assessment checklist descriptor. Moreover, it will train the students to make decision for themselves, and not only wait for the teacher to tell them about their mistakes in writing.

Next, the prototype designed in this present study was developed considering the syllabus, assessment task and assessment criteria. It means that the product developed is suitable with the syllabus and the self task developed. It can be stated 
that the product developed is suitable with students needs so that it is appropriate to be implemented in the classroom.

The content validity of the instruments is very high and the practicality of the instrument was excellent. Both means that the self-assessment instruments developed met the requirements of ready to be used instruments to be applied in the classroom since it is measured already by expert judges and user judges who are expert in this field.

\section{CONCLUSION AND RECOMMENDATION}

From the data analysis it was found that the self-assessment instruments needed by teachers are self-assessment which focuses on the learning development of students considering the students' different level of competency.

The prototype of self-assessment contains assessment criteria, assessment task, planning checklist, draft checklist, and self reflection. In the writing task, the students must filling in the gap text, arranging sentences into a meaningful paragraph, and writing a simple essay.

The quality of the instrument by the expert judges was deemed excellent and the practicality deemed as good by user judges. The content validity of the instrument by using Gregory formula was 1 , which was classify as very high referring to the validity criteria. Furthermore, the Mi+1.5Sdi from the user judgment was 35.75, the $\mathrm{Sr}$ was 36.5 and the Mi $+3.0 \mathrm{Sdi}$ was 2.5 , so referring to the criteria, the self- assessment instrument developed was considered excellent. ( $\mathrm{Mi}+1.5 \mathrm{Sdi} \leq \mathrm{Sr}<\mathrm{Mi}+3.0 \mathrm{Sdi}$ $=$ Excellent $),(\mathrm{Mi}+0.5 \mathrm{Sdi} \leq \mathrm{Sr}<\mathrm{Mi}+1.5 \mathrm{Sdi}=\mathrm{Good})(\mathrm{Mi}-0.5 \mathrm{Sdi} \leq \mathrm{Sr}<\mathrm{Mi}+0.5 \mathrm{Sdi}=$ Average $),(\mathrm{Mi}-1.5 \mathrm{Sdi} \leq \mathrm{Sr}<\mathrm{Mi}-0.5$ $\mathrm{Sdi}=$ Below Average) $(\mathrm{Sr}<\mathrm{Mi}-1.5 \mathrm{Sdi}=$ Poor $)$. In the other hand, it can be said that the instrument is ready to be used by junior high schools teachers at SMP N 12 Padang to assess students' writing competency.

Based on the research conducted, there are some suggestions that can be proposed: (1) The students: By using the selfassessment instrument in the correct way,.(2) for teachers: It is recommended treat the findings as the model for developing assessment instrument for different type of material. This finding can be considered as the first hand reference for conducting further research in the EFL area of pedagogy in general or teaching of writing in particular.

\section{References}

Branch, Robert Maribe. (2009). Instructional Design : The ADDIE Approach.New York : Springer Science \& Business Media, LLC.

Brown, H, Douglas. (2005). Language Assessment Principles and Classroom Practices (Second Edition). New York: Pearson Education, Inc.

Byrne, D. (1993). Teaching Writing Skills. London: Longman Group UK.

Candiasa, I M. (2010). Statistik Univariant dan Bivariant Disertai Aplikasi SPSS. Unit Penerbitan Universitas Pendidikan Ganesha Singaraja

Dantes, N. (2012). Metode Penelitian.Yogyakarta: Penerbit Andi

Harris, D. P. (2005). Testing English as a Second Language. Bombay: Tata-McGraw Hill \& Co.

Harmer, J. (2004). "How to Teach English Writing." Pearson Education Limited.

Langan, J. (2002). English Skills with Writing. Boston: the McGraw-Hill Companies

Marhaeni, A.A.I.N., Dantes, N., \& Artini, L.P. (2013). Pengembangan Perangkat Asesmen Autentik sebagai Asesmen Proses dan Produk dalam Implementasi Kurikulum Tingkat Satuan Pendidikan (KTSP)

Nitko, A.J. Educational Assessment of Students. New Jersey:Prentice-Hall Inc.

Srimavin, W and Darasawang, P. (2004). "Developing Self-assessment through Journal Writing". Available at: http://independentlearning.org/ILA/ila0 3-srimavin-and-pornapit.pdf

Sorenson, S. (2000). Student Writing Handbook.Foster city: websters' new world

Sugiyono. (2011). Metode Penelitian Kuantitatif, Kualitatif, dan R\&D Bandung: Penerbit Alfabeta.

Wiggins, G. (1996). Educative assessment: Designing Assessments to Inform and improve student performance. San fransisco: Jossey-Bass publishers. 